\title{
Household Solid Waste, a Challenge of Urban Sanitation: Case of Ngor Municipality (Dakar, Senegal)
}

\author{
Ramatoulaye Mbengue Ndiaye ${ }^{1,3}$, Bouna Ndiaye ${ }^{4}$, Vieux Boukhaly Traore ${ }^{2,3}$, \\ Amadou Tahirou Diaw ${ }^{1,3}$ \\ ${ }^{1}$ Department of Geography, Faculty of Letters and Human Sciences, Cheikh Anta Diop University, Dakar, Senegal \\ ${ }^{2}$ Hydraulics Laboratory and Fluid Mechanics, Cheikh Anta Diop University, Dakar, Senegal \\ ${ }^{3}$ Polytechnic High School's Geoinformation Laboratory, Cheikh Anta Diop University, Dakar, Senegal \\ ${ }^{4}$ Polytechnic High School's Cheikh Anta Diop University, Dakar, Senegal
}

Email address:

ramatoulaye5.mbengue@ucad.edu.sn (R. M. Ndiaye)

\section{To cite this article:}

Ramatoulaye Mbengue Ndiaye, Bouna Ndiaye, Vieux Boukhaly Traore, Amadou Tahirou Diaw. Household Solid Waste, a Challenge of Urban Sanitation: Case of Ngor Municipality (Dakar, Senegal). American Journal of Remote Sensing. Vol. 9, No. 1, 2021, pp. 47-54. doi: 10.11648/j.ajrs.20210901.16

Received: November 15, 2019; Accepted: December 17, 2019; Published: April 26, 2021

\begin{abstract}
This study aims to understand factors that are causing the malfunction of the garbage collection system in the municipality of Ngor. To achieve this goal, we have adopted a methodological approach that focuses essentially on three components: (i) the investigation of $1 / 4$ of Ngor's concessions through observation, interviews, questionnaires and documentation for collect socio-economic data; (ii) GPS surveys and mapping of the study area using GIS techniques and tools based on satellite images; (iii) analysis of collected information based on descriptive statistics. The results obtained reveal a bad garbage collection, which is at the origin of the insalubrities, the development of flies, mosquitoes and rodents having repercussions on the frame of life of the populations. It is also at the origin of the narrow streets, thus making access to neighborhoods difficult; this leads people to dispose of garbage in the open air or on the beach and in the evacuation channels, to the detriment of environmental concerns. This study has clearly highlighted deficiencies of human nature in the system of collection of household garbage in the municipality of Ngor. These results should provide the municipal authorities with a basis for thinking about the reformulation of their system of governance of such garbage and their political will to definitively solve the problem.
\end{abstract}

Keywords: Sanitation, Challenge, Management, Household, Solid Waste, Ngor

\section{Introduction}

Today, the world is under the influence of many natural and human crises that shake and threaten its existence [1-2]. Man, by his multiple actions, contributes to the permanent degradation of his environment [3-6]. The pollution of the air, the soil, the water and the climatic crises are as many threats that weigh on the environment in general and the Man in particular [7-8]. However, it is not the quantity of waste that poses a problem, but rather the inability to get rid of it in many shanty towns and slums which are the favorite places for the disposal of all household waste, industrial waste, manufacturing, agricultural and sewage sludge [9]. Like other major African cities, the city of Dakar is one of the major municipalities with serious problems in solid waste management [10]. According to [11-14] waste management is a contemporary and global challenge. In the opinion of [15], human activity has always resulted in the generation of waste, however, the growth of it and the change in nature of these generate additional negative externalities. Stronger that force us to review our methods of treatment. According to the latter, the transition from hygienist management to a logic of environmental protection becomes imperative. $[16,17]$ add that the industrial age has indeed favored the production of more and more waste by both industry and consumers. Today, global annual waste production is estimated at around 4 billion tons, for example France produces 868 million tons a year, twice as much as 40 years ago [10]. Due to the growing urban population and the rising standard of living, it is expected that the amount of garbage generated by urban 
dwellers will increase sharply by 2025 . Today, 1.3 billion tons per year, this volume is expected to increase to about 2.2 billion. The bulk of this increase would come from fast-growing cities in developing countries [4]. In the case of Senegal, household solid waste management has become a major concern for state authorities in general and municipal authorities, such as Ngor in particular [18, 19]. After a period of crisis in waste management, this sector has had a strong involvement of private actors [18-20]. Similarly, important efforts have been made with the support of technical and financial partners for the strengthening of the system with appreciable results. In spite of the positive change observed in the management of solid household waste, it is clear that in certain urban neighborhoods, such as along certain streets, spontaneous garbage disposal is a distressing sight on the coast. Improving the sanitary status of the municipality of Ngor requires a greater environmental awareness of all stakeholders, the establishment of adequate infrastructure and the improvement of the working conditions of the collection agents. The magnitude and the urgency of the situation justify this study, which intends to contribute to the collective challenge. Specifically, it aims to draw the attention of the community to the importance of waste recovery and recovery activities in improving their living conditions.

\section{Geographical Context and Production Context of Household Solid Waste}

Ngor is located at the western end of the head of the Cape Verde Peninsula, between latitudes $14^{\circ} 44^{\prime} 37^{\prime \prime}$ North and longitudes $17^{\circ} 30^{\prime} 53^{\prime \prime}$ West. It is limited to the West, South and North by the Atlantic Ocean and to the East by the communes of Yoff and Ouakam (Figure 1). It covers a total area of 4.5 $\mathrm{km}^{2}$. It consists of Ngor village, so-called residential quarters of Almadies, Ngor turn and the island of the same name. Ngor village (traditional village) is characterized by compact dwellings with originally the districts of Grand Ngor, Petit Ngor and Ndiogorann and Ndare (next to the old well of Ngadié). However, in the context of land consolidation of the Almadies and Ndaré sectors, the cadastre services had subdivided the Almadies' residential neighborhoods into 18 zones. The zoning carried out in this space facilitates the addressing of services such as Sonatel, the Post Office and the Sde. We have a river network in the commune that is rudimentary and is made mainly of streams like Ouaya Diafey, at the height of the bend located at the entrance of Ngor village, Ouaya Ngadié whose outlet is located at the bay carp. Indeed, these streams now house sanitation channels. Fishing and tourism are the dominant activities in the study area.

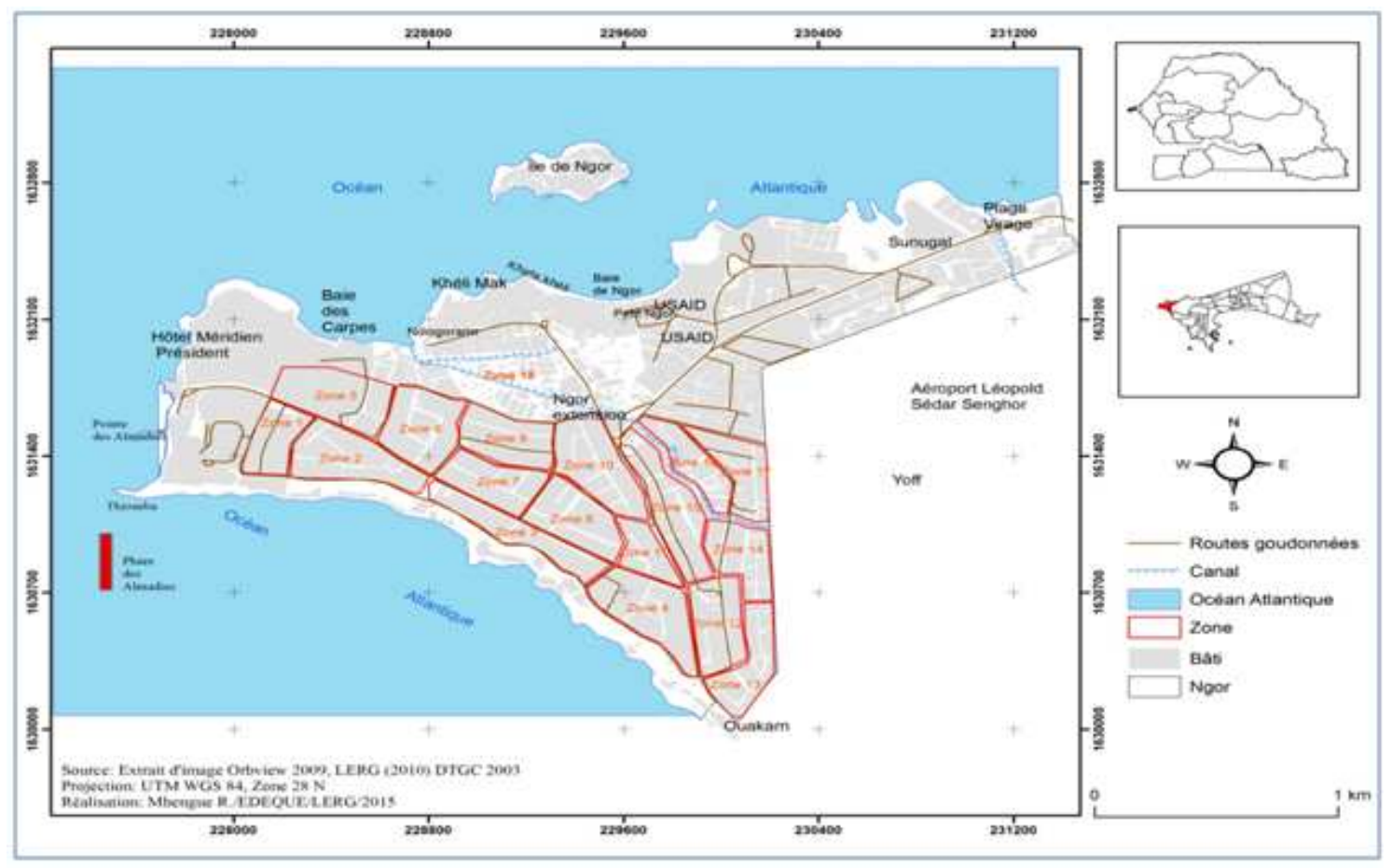

Figure 1. Location of the study area.

\section{Data and Method}

This study is essentially based on the mapping and collection of quantitative and qualitative data from the study area. Indeed, we have previously proceeded to the acquisition of quantitative data relating to actors operating in waste management (Commune, concessionaire, garbage collectors, GIE, NGOs, carters, etc.), by sampling at $1 / 4$ the concessions to Ngor. This operation led to the development of a questionnaire administered to 203 people at random (only one household was interviewed by concession). This second step made it possible to collect all the necessary information on the issue (interview guides for the persons in charge of the management of household waste with the populations, the municipality and the different actors). It is a question of trying to understand the actions taken by the City Council in 
the management of household waste. This approach has produced data and information related to household solid waste management, the adoption of various methods of treatment and analysis of learning. Subsequently, we moved to digitizing satellite images using Arc GIS software and GPS field surveys. This first step made it possible to assess the location and highlight the waste management practices in the municipality of Ngor. The third step was the analysis of collected information based on descriptive statistics and content analysis. Our motivation through this study is to encourage people to participate in the activities of recovery and recovery of household waste to improve their living conditions. It should be noted that the study related to the waste, is of a plural interest in particular on the plan: professional, political, scientific, economic, and social.

Table 1. History of urban solid waste management in Dakar.

\begin{tabular}{|c|c|c|c|c|}
\hline Periods & Project manager & Status & System & activities \\
\hline $1960-1971$ & Municipal services & Public & Public monopoly & Sweeping Desensibly Collecting and Evacuating OM \\
\hline 1971- 1984 & SOADIP & Private & Private monopoly & Sweeping Desensibly Collecting and Evacuating OM \\
\hline $1984-1985$ & CUD & Public & Public monopoly & Sweeping Desensibly Collecting and Evacuating OM \\
\hline $1985-1995$ & SIAS & $\begin{array}{l}\text { Mixed } \\
\text { economy } \\
\text { company }\end{array}$ & $\begin{array}{l}\text { Public monopoly of } 5 \\
\text { years renewable } \\
\text { Scanning Desensably }\end{array}$ & Collection and evacuation ofOM \\
\hline $\begin{array}{l}\text { October } \\
\text { December } 1995\end{array}$ & AGETIP test phase & Private & $\begin{array}{l}\text { Competitive selection } \\
\text { of companies, } 3 \text {-year } \\
\text { service contracts }\end{array}$ & $\begin{array}{l}\text { Sweeping Desensibly Collection and evacuation of OM, } \\
\text { landfill O. M }\end{array}$ \\
\hline $\begin{array}{l}\text { January } 1996- \\
\text { July } 2000\end{array}$ & $\begin{array}{l}\text { CUD, AGETIP, Companies, } \\
\text { Consortium Senegalo } \\
\text { Canadian, CAMCUD, GIE, } \\
\text { concessionary companies }\end{array}$ & $\begin{array}{l}\text { Private } \\
\text { public }\end{array}$ & Private public & $\begin{array}{l}\text { Scanning, collection, transportation, disposal, monitoring } \\
\text { and tracking, information and awareness, planning, } \\
\text { financing, coordination, steering and implementation }\end{array}$ \\
\hline $\begin{array}{l}\text { July } 2000 \\
\text {-March } 2001\end{array}$ & PRODAK & $\begin{array}{l}\text { Private } \\
\text { public }\end{array}$ & Private public & Household waste management \\
\hline $\begin{array}{l}\text { March } 2001- \\
\text { January } 2006\end{array}$ & $\begin{array}{l}\text { APRODAK, Alcyon, AMA, } \\
\text { CADAK-CAR Ministry of the } \\
\text { Environment, }\end{array}$ & Private & Private public & $\begin{array}{l}\text { Coordination, monitoring, control, implementation of the } \\
\text { urban solid waste management program, complementary } \\
\text { actions of sanitation and hygiene cleaning }\end{array}$ \\
\hline $\begin{array}{l}\text { Since January } \\
2006\end{array}$ & $\begin{array}{l}\text { CADAK-CAR APROSEN, } \\
\text { MEPN }\end{array}$ & $\begin{array}{l}\text { Private } \\
\text { public }\end{array}$ & Private public & $\begin{array}{l}\text { Sweeping Desensibly Collection and transport to the } \\
\text { Mbeubeuss landfill, landfill O. M }\end{array}$ \\
\hline 2012-2014 & CADAK - CAR & Public & Public & $\begin{array}{l}\text { Sweeping Desensibly Collection and transport to the } \\
\text { Mbeubeuss landfill, landfill O. M }\end{array}$ \\
\hline
\end{tabular}

Source: Technical Services Branch / CUD, 1995; CADAK-CAR, 2007, adapted.

\section{Results}

\subsection{History of Waste Management in Senegal}

Since independence, Senegal has experimented with several schemes of household waste management but is struggling to find a lasting solution (Table 1). From the independence of Senegal, in 1960 to 1971, the municipal services represented the key actors of the management of garbage: collection and transport. The collection was done using horse-drawn transport. The waste was dumped in the quarry at Hann. Increasingly forced to perform this service, the municipality has to sign a concession contract with the African Broadcasting and Promotion Corporation (SOADIP). So; from 1971 to 1984 , this private company handled the cleaning and garbage collection of Dakar, Pikine and Rufisque with small vans for cleaning, compression bins and containers. The contract with SOADIP benefited from the first transfer stations before the landfill at Mbeubeuss. Financial difficulties still subsist and the municipality is struggling to pay for the services offered by SOADIP, which will go bankrupt in 1984 no longer able to meet current maintenance and renewal expenses. From 1984 to 1985, we are witnessing the introduction of the newly created urban commune of Dakar (CUD), which deals directly with waste management until
1985 through its concessionaire: the urban planning industrial society of Senegal (SIAS), a semi-public company with majority State ownership. In turn, due to delays in payment and technical and managerial problems, the SIAS can not continue the mission in which it engaged and was dissolved in 1995. From 1995 to 2000, the CUD entrusted the mastery of AGETIP work that involves several actors such as Senegalese private companies and neighborhood GIEs. According to [10] the involvement of the national private sector has played a decisive role in the eradication of wild deposits with the zoning of the municipality for the disposal of waste. However, the accumulation of financial deficits has not allowed the sustainability of the CUD that will be broken in 2000 by the new government for the benefit of the High Authority for Cleanliness of Dakar (PRODAK) who inherit the management of household waste. It will become APRODAK, Agency for the Cleanliness of Dakar (authority and operational) in 2001. The government signs a contract with Alcyon S. A, entrusting to him the solid urban waste management of the region of Dakar. APRODAK manages the monitoring and control of the services. In 2001 the State of Senegal assigns the contract to AMA International, subcontractor Alcyon SA and APRODAK monitors and controls the execution on behalf of the Minister of the Environment. AMA encounters dysfunctions of the system in 2003 which leads to total insalubrity and its contract is broken 
in 2005. The State transfers in 2006 the management of the urban management program to the CADAK CAR Agreement which is a dismemberment of the local communities. In 2006, the national agency for the cleanliness of Senegal was set up. Today, waste management is in a transition phase. In 2011, the State realizes that the municipalities of Dakar do not manage to ensure proper waste management and takes charge of this management by setting up the Solid Waste Management Coordination Unit (UCG). The latter is a state structure that should manage the transitional phase between the CADAK agreements. The Dakar region being a particular case: "the gateway to Senegal and Africa" [21], the state has allowed the region to benefit from a specific status and will continue to finance the management of waste through a special fund because local authorities would not have the means to ensure this management. In addition, the Mayors, through the Technical Services Department (DST) also take charge of certain aspects of waste management: road works, public lighting, sanitation and the fight against insalubrity. It should be noted that household solid waste management only supports household waste, markets and public spaces with only one mode of treatment: landfill towards Mbeubeuss. The Dakar region being a special case: "the gateway to Senegal and Africa" [22], the state has allowed the region to benefit from a specific status and will continue to finance the management of waste through a special fund because local authorities would not have the means to ensure this management (475000 tons of waste per year are dumped).

\subsection{Waste Generation}

The Environmental Code defines waste as "any residue from a production, processing or use process, any substance, material, product abandoned or that its holder intends to abandon". The amount of waste generation varies from one region to another and from a developed to a developing country. In Third World countries, solid waste production is 0.4 and $0.8 \mathrm{~kg}$ per person per day. It is different from one city to another. In the Senegalese capital, Dakar, the variation in household waste production reduces it to 244 $\mathrm{kg} /$ inhabitant/year. Waste production is estimated at $10918 \mathrm{~kg}$ per day. Surveys conducted in the Commune show that waste production varies from one concession to another. Thus, determining the amount of waste was not easy, as households also use several types of waste bins for home storage.

\subsection{The Organization of the Collection}

The organization of waste collection has experienced many dysfunctions in Senegal in general and in the commune of Ngor in particular. With institutional change, waste management is experiencing instability by key actors. Indeed, garbage collection is mandatory and is governed by the environmental code as being the collection, transport, storage, recycling and disposal of waste, including the monitoring of disposal sites. The disposal of household waste is necessary for health and sanitation reasons. Waste collection is carried out by the city of Dakar, which hires concessionaires to collect waste in the municipalities. The city of Dakar is divided into 19 municipalities on the basis of Decree 96-06 of 30 August 1996. The purpose of this reform was to bring the populations closer to the elected representatives and to enable them to participate in decision-making processes, particularly in the areas of competence transferred. In Ngor, the Mame Ndague dealer is in charge of collecting and disposing of waste. For collection, it has made available a 12-tonne capacity compacting bucket for waste collection. As can be noted, the household solid waste management system is constrained by a variety of constraints. Indeed, in Ngor, beyond the weakness of logistical (car fleet) and human (staff) resources, access to the interior of the districts is difficult; the narrowness of the alleys obliging collection trucks to limit themselves to the entrance to Ngor village on the main roads.

In the traditional village, the disposal of solid household waste is conditioned by the structuring of traditional housing. As a result, the collection system, serving traditional villages and certain districts, represents only a small part of the places where household waste is produced. The rest is dumped anarchically along the beach, the public road and not far from the houses causing pollution of all kinds.

Figures 2 and 3 show that people abandon waste anywhere. Waste fills channels and empty spaces.

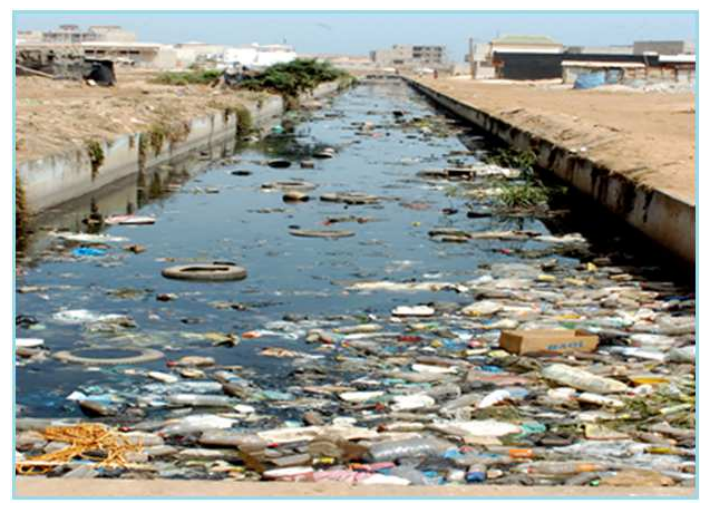

Figure 2. Uncontrolled dumping of garbage.

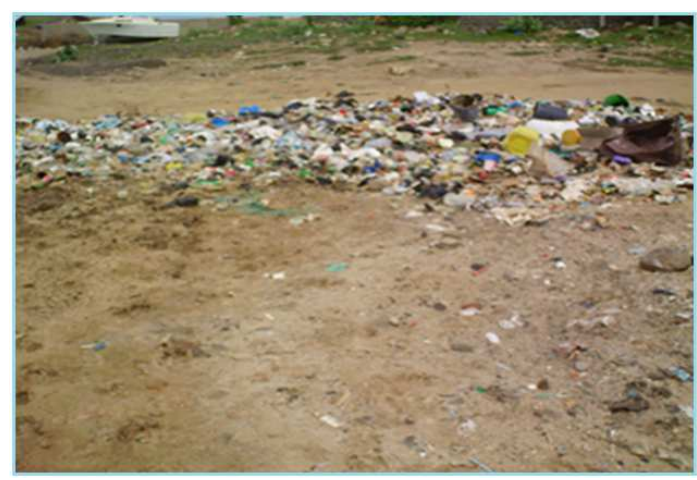

Figure 3. Anarchic garbage dumping on the channel.

The neighbourhoods closest to the paved streets are best served by collection trucks. These are generally the Almadies and Ngor Meridien districts. Garbage disposal is door-to-door. Households wait for the horn on the collection truck to take out the garbage. In this area, the exit of waste is under the 
responsibility of the guards in majority, children and housewives. In these neighbourhoods, which are well served in terms of collection or collection, the presence of garbage dumps was identified in October 2019.

The island of Ngor, the last entity, is a small island off the Cape Verde peninsula $400 \mathrm{~m}$ from the village of the same name Ngor. To get there, the most common way remains the crossing by pirogue from the beach of the village of Ngor. On the island, there are various infrastructures (hotels, restaurants, artists' and sellers' stalls). Only four houses are permanently inhabited on the island. Waste production varies according to the time of year (December-January and June-October). The importance of the production is the responsibility of the visitor and is done during the day.

\subsection{Inappropriate Collection}

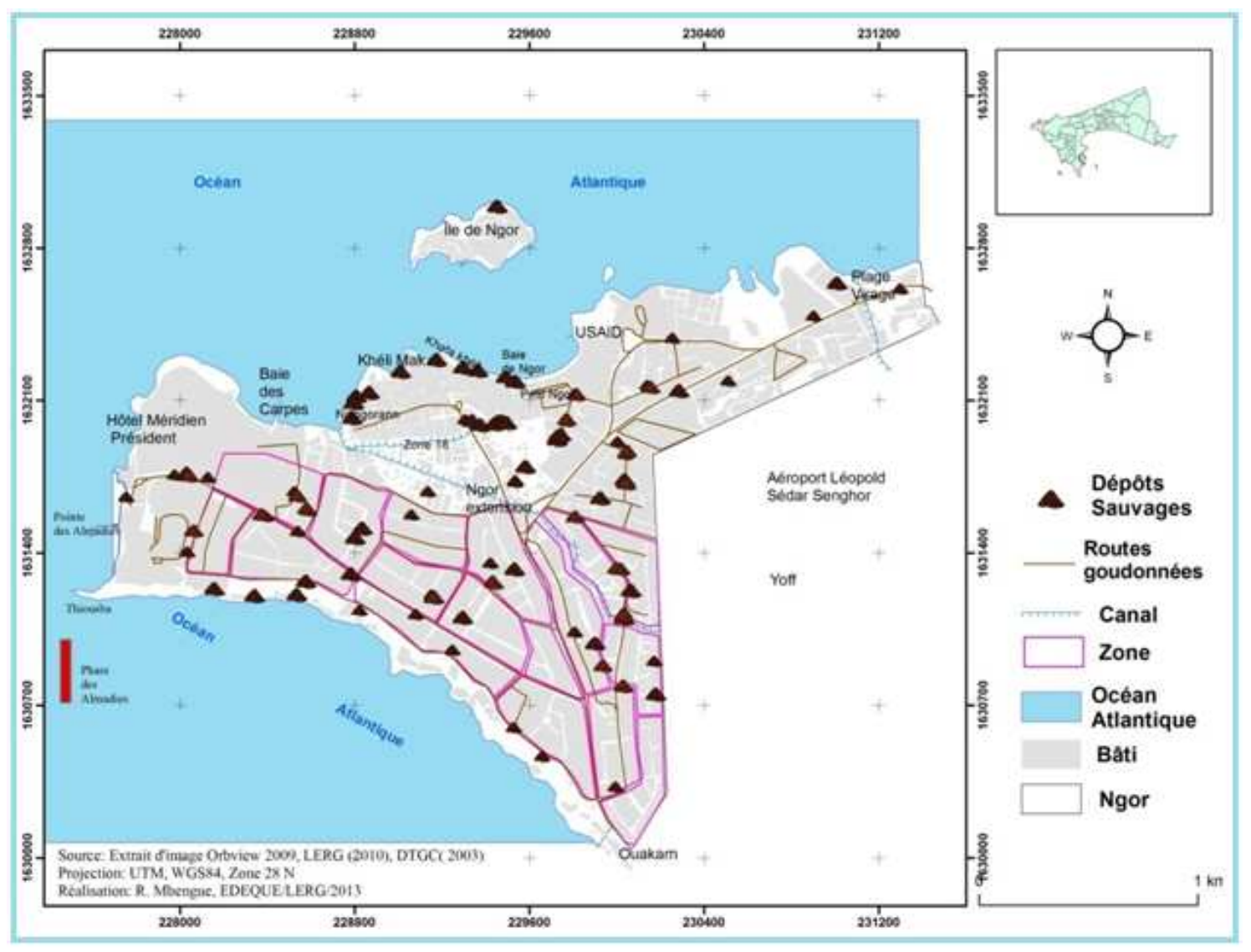

Figure 4. Consequence of improper collection: Wild deposits.

\subsection{Descriptive Analysis}

The majority of them believe that these deposits result from the irregularity of the collection or the absence of collection (Figure 5). This figure shows that two reasons were raised by the populations, they denounce the absence of collection and other by the irregularity while the rest which has not pronounced because it profits from the daily collection. Rubbish attract rats, dogs, flies and mosquitoes that are vectors of disease and epidemics. The health risks are therefore very high (Figure 6). Health data show that at the Ngor village level, the reasons for consultation and morbidity
The rapid and uncontrolled traditional urbanization linked to a high population growth creates an organizational failure in the collection: some parts of the Commune are inaccessible areas. Spatial occupation is characterized by spontaneous habitat with areas where the roads are narrow, unpaved, sandy in other words, impractical for the dump trucks used by the collection. This is evidence of access to the collection service very unequal neighborhoods. In the traditional village of Ngor, the streets are too narrow for the whole village to be served by the collection system. Malfunctions of the system are manifested by the development of alternative behaviors of populations. They abandon waste (Figure 4) in nature that can be very harmful to their environment and their health. Thus, not all waste products are collected per day land in the sometimes permanent wild dumps. According to our study, $68 \%$ of respondents point out that there is a junk yard near their home. 
from heart disease (...), lead to disturbances in sex ratio and congenital malformations "[23].

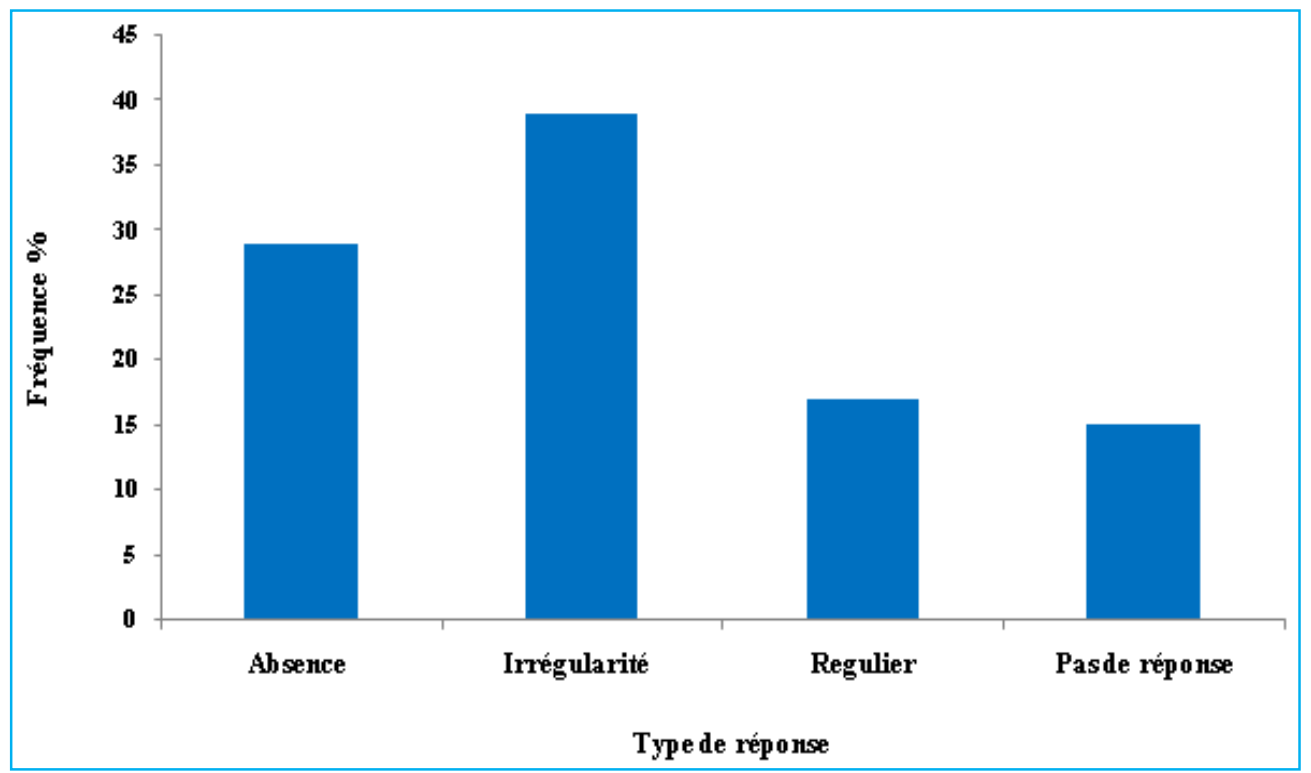

Figure 5. Reason for Feeding Wild Deposits.

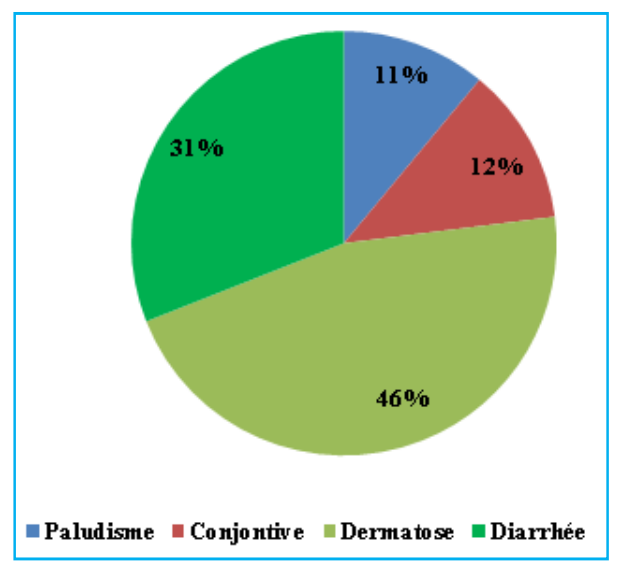

Figure 6. Distribution of the main diseases in Ngor.

\subsection{Regulation and Control}

Various laws and regulations have been adopted by Senegal for the management of solid waste: the law on the code of hygiene, the law on the environment code, the law on the code of local authorities and the decree regulating the collection garbage. The setting up of these is not accompanied by any measure of effective implementation; they had no effect not only because of their overhaul in relation to the needs, technical, technological, environmental and economic constraints, but also because of the lack of complementarity between them. However, it is necessary to emphasize their ignorance of the populations. Regulations and their application also face many difficulties, given the inapplicability of certain laws, public ignorance of regulations, lack of control and sanctions. The enforcement of laws and regulations suffer from a lack of control and punishment resulting from the total impunity deficit for concessionaires, garbage collectors and households. At all stages, there is a let do in the various links in the management of household waste (non-compliance with environmental rules). Today, according to the maintenance guides observed in Ngor, there are always the hygiene services but they are struggling to perform their role properly. They do not have logistical means for their displacement. Frequent control and sanctions must be made against the dealers as they put strategies to make their tour more profitable. During the follow-up of the grab, we noted that the team leader changes a circuit for another either to make money or to have more waste. At the end of the circuits inside Ngor, he asks the driver to stop on the way to collect the waste, which will mow the tonnage allocated the tonnage on the production allocated to this space. According to the manager of the waste pickers, the dealers can be in complicity with the Mbeubeuss postmaster. The latter allows him to do two to three weighing a day to have more ton at the end of the month. With this in mind, the control of all those responsible for the garbage management link becomes mandatory. We can also evoke the omnipotence of Senegalese politicians who under cover of the management of garbage massive their party by creating fictitious jobs in the administration; which obviously weighs on the costs of management. Some mayors or district politicians go so far as to ask their sympathizers to maintain insalubrity or even to proliferate in public places in order to harm their political opponent [19].

\section{Discussion}

For a long time, the appreciation of environmental problems in any form whatsoever has been a simple exercise to satisfy the curiosity of researchers. It was not until the second half of the twentieth century, especially at the Earth Summit in Rio de Janeiro in 1992, that environmental problems became a matter of great concern to both developed and developing countries. are being developed as well as for researchers. These environmental problems include those related to poor waste management in urban areas. Our results show that waste management is a victim of government changes with frequent changes in management. We noted that there is no institutional 
continuity. Thus, repercussions were noted on the way of managing but also on the employees. They should allow a better improvement of care because no evaluation is made after the event. Other authors have shown that there has been no evolution or concertation or sharing of the systems that have succeeded one another [24]. Thus, the new leader does not have a set of responsibilities allowing him to learn from the experiences of his predecessor [10]. A lack of transparency and coherence [25]. Dealers have never been chosen with predefined criteria. They are selected because they have logistical means to carry out this collection and transport of waste until the landfill in Mbeubeuss. According to YASSI G A [26], the causes of environmental problems are multiple and diverse. In this regard, the international community and scientists were invited to the Rio de Janeiro Summit to take steps to better control the impacts of human activities on the environment. This awareness of the international community of environmental problems is sanctioned by conventions and declarations [1]. It has to be said that the measures taken are in different forms from one country to another depending on the level of awareness, the scale of the environmental problems on development and the capacity of each country to deal with these problems. [27-28]. The efforts made by the rulers, sometimes under the impetus of the populations, sometimes under that of the non-governmental organizations and international organizations to adhere to the international texts and for a better management of the framework of life and waste, mainly relate to the establishment of the legislative and institutional framework followed by sporadic and uncoordinated actions through different projects funded by development partners [19]. In some countries, the many pieces of legislation voted by the legislature suffer from the decree of application that should be taken by the executive and technical support for their application [29-30]. This situation would result according to [31] on the one hand, natural causes (wind, runoff) and, on the other hand, population growth and human actions. Despite the decline in its annual growth rate (3.89\%) over the past ten years, population growth is still increasing in Cotonou [32]. However, some would no longer be viable today but continue to exercise, for lack of serious studies. Specialists also denounce the lack of transparency [33] in the remuneration of certain actors. For example, the concessionaire Veolia takes over the areas of Dakar's downtown area, described as "easier by Dakar" by Ibrahim Diallo, and paid three times more expensive per ton (more than 33,000 FCFA per ton) than other local concessionaires whose better paid receive 7500 FCFA per ton. [34-37]. How to explain the gap [10] that exists in remuneration rationally? Mbaye Fall Diallo, Program Manager at UCG, refers to "technical reasons" which seems unrealistic given the characteristics of these collection areas. The instability of the institutional framework also poses serious administrative and legal problems that weigh on employees in this sector who are ultimately the only constant in the system [21, 38-40]. Indeed, Guèye, points out that since 2006, employees have no social benefit, no premises and suffer full wage delays. Cissé Diagne, shiver in the city of Pikine insists meanwhile the absence of pay slips and convention in December 2012 through the Minister of
Planning and Territory which has not yet been followed effect. These administrative complications added to the difficult working conditions and attitude sometimes

\section{Conclusion}

The objective of this study was to understand the factors that are causing the malfunctioning of the garbage collection system on the Ngor coastline. To see clearly, we conducted fieldwork based on observation, direct interview and socio-economic data collection, GPS surveys and satellite image processing. This leads to the following results: the frequency of garbage collection in Ngor, varies from one area to another, which leads to insalubrity, the development of flies, mosquitoes and rodents with repercussions on the living environment populations; the narrowness of the streets makes the neighborhoods of Ngor village inaccessible, thus leading people to abandon garbage in the open air, on the beach as well as in the canal, which negatively affects the environment of the beaches. Given these different results, we are questioning the human failures in the waste collection system in Ngor. Despite some ad hoc efforts by the authorities through the CADAK-CAR Agreement, it is sad to note that household solid waste continues to litter the streets, arterials and streets, public places and some wild dumps that tarnish the image of the city. It is therefore time for the authorities to initiate deeper policies by giving the necessary means to the people it takes to better relieve people. However, it is also time for people to recognize their mistakes and urgently opt for a change of behavior to improve their own living conditions. It is then necessary to inform these populations properly and to enable them to participate in the cleansing of their cities. For that, it is necessary on the one hand an information system and on the other hand of the systems of governances governed by a political will.

\section{References}

[1] ADAM, I. 2007: Collection, handling of household solid waste (DSM) and athological risks in carters in the city of Cotonou, Master's thesis, FLASH, Univ. D'Abomey-Calavi, 61 p.

[2] BA I. S., 2008, Problem and strategy of solid urban waste management, example of the city of Nouakchott (Mauritania), Master thesis, ISE / UCAD, 85 p.

[3] GOUHIER J. 2000, Beyond the waste, the quality territory, Manuel de Rudologie 79 P.

[4] ONIBOKUM A. G., 2002, Urban Waste Management, Solutions for Africa, IDRC - Karthala, 238 p.

[5] ADEPOJU G. O, 2001, Urban Waste Management. Solutions for Africa, Ed Karthala and IDRC, Paris, 250 p.

[6] BIHIDINDI A., 2002, Sustainable management of waste in urban areas State of play and prospects for technology transfer from Vietnam to Senegal for recycling waste. Brief of DEA, ATEGU, ENEA Dakar, 95 pp. + Annex.

[7] CISSE O., 2008, Mbeubeuss; ecological bomb or source of life? In Life (Green Environmental Information), No. 8, pp. 7 to 46. 
[8] D. Dietman 2008 Household waste. The garden impostors. Edition Harmattan, 160 P., P10 to 68.

[9] Ericson, O., Carlsson Reich, M., Frostell, B., Bjorklund, A., Assefa, G., Sundqvist, J. O., Granath, J., Baky, A., Thyselius, L., 2005. Municipal solid waste management from a system perspective. Journal of Cleaner Production 13, 241-252.

[10] SIDIBE C. 2013, Articulating conventional and unconventional waste management in the Dakar region: a contemporary challenge. Master's thesis 2; Geography and Development University of Maine-Le Mans-Laval, UFR Letters, Languages and Human Sciences, 105 p.

[11] WASS E., 1992, Urban Waste, Plural Waste Introductory Introduction In Waste and People, African Environment. P. 7-20 Ibid.

[12] DIOP O. E., 1992: Solid Urban Waste Management: "The African Problem", International Seminar on Waste Management, Montreal, 15 pages.

[13] MAYSTRE L. Y. et al: 1994, Urban Waste: Nature and Characterization. Polytechnic and University Press Romandes (PPUR), $220 \mathrm{p}$.

[14] COUlibaly, G. M. M. Z. 1997, Domestic Production, Recovery and Recycling of Plastic Waste; Case of plastic waste in Dakar, PhD thesis in environmental sciences, ISE, UCAD, FST, $141 \mathrm{p}$.

[15] SECK M, 1997. Waste management in Dakar, perceptions and environmental effects. Ph.D. thesis 3rd cycle. UCAD-Department of Geography 310. P.

[16] HEBETTE A., 1996, Practical Guide to Urban Solid Waste Management in Sub-Saharan Africa CREA-AO World Bank $151 \mathrm{p}$.

[17] Mbayu Kapepula b, Gerard Colson a, *, Karim Sabri b, Philippe Thonart c, 2006, A multiple criteria analysis for household solid waste management in the urban community of Dakar. Waste Management 27 (2007) 1690-1705.

[18] DIOUF M., 2007, Local Practices of Sustainable Urban Development in the Dakar agglomeration, Case of the Municipality of Arrondissement NGOR. ENEA Department of Regional Planning, Environment and Urban Management (ATEGU) Master thesis, $190 \mathrm{p}$.

[19] MBENGUE. R., 2010, Management and environmental impacts of household solid waste in the Ngor District Municipality, Master's thesis 2 Integrated Management and Sustainable Development on the West African Coast, University Cheikh Anta DIOP Dakar, Department of Geography, 74 p.

[20] Mbengue Ramatoulaye. Strategies for local management of urban solid waste in Ngor. Forms of sanitation organization and problems. PhD, EDEQUE, FST, UCAD, 2015, 300 p.

[21] CISSE O. \& WONE S. S, 2013, waste management in Dakar (2000-2012) the institutional Imbroglio. Momar-Coumba Diop (dir), CRES-Karthala, (2012) pp 759-788.

[22] Thibault V., 2001, Environment and Urban Development, Sanitation and Household Waste Management in the city of Thies (Senegal). Internship memory, Strasbourg, $122 \mathrm{p}$.

[23] Julien Rouyat Cecile Broutin, Virginia Rachmuhl Ahmed Gueye, Valentin, Torrasani Ibrahima Ka, STUDIES AND
WORK ONLINE EDITION \# 8 GRET, WWW.Org 2006: Household Waste Management in Secondary Cities of Senegal towards Policies including municipal suburbs. 91 pages.

[24] CISSE O. 2012, Garbage dumps in Africa Mbeubeuss in Dakar, Senegal, Karthala and CREPOS, 329 p.

[25] DJIGO A, 2005 "Sanitation of wastewater and its impact on the health and social situation of the populations of Medina-Gounass", Memory.

[26] YASSI G A., 2006. Production and management of household waste in the urban space, the case of the municipality of Adzop.

[27] APROSEN, 2006, National Strategy for integrated and sustainable solid waste management in local authorities, GES-Concil, Dakar, 87 p.

[28] DIOP O, 1988. Contribution to the study of solid waste management in Dakar. Systemic analysis and decision support. $\mathrm{PhD}$ thesis in technical sciences, EPFL, Lausanne.

[29] WANE O. A. 1981, Contribution to the study of the environment in Senegal. Residual matter and urban disparities in an African city, Dakar, doctoral thesis, 3rd cycle, specialist urban planning and development, mention planning and environment, ISE, FST, UCAD, 382 p.

[30] PICHAT, P. 1995: Household solid waste management, Editions Dominos and Flammarion, Paris, 124 p.

[31] ATTAHI K. 1996 the problem of urbanization and the challenges of municipal management in West and Central Africa, article by BNETD and PGU, Abidjan, 23 p.

[32] ADEGNIKA, F. M. 2004: Household solid waste management in urban Africa under the double constraint of public service and economic efficiency: case of Cotonou, memory of DEA, EDP, FLASH, University. Of Abomey-Calavi, 50 p.

[33] Mbengue R., 2009: Problems in the collection of household solid waste in the town of Kaolack, Master's Dissertation UCAD Department of Geography, 152 pages.

[34] DASILVA R. M. F. F. 2008, Urban and risky environmental extension in the Mbao area. Dakar, Senegal. Memory of DEA, ISE, $107 \mathrm{p}$.

[35] DELBECQ 2009, Waste and pollution, Impact on health. In Studies of the ADEME, Paris, $47 \mathrm{p}$.

[36] CADAK-CAR, May 2007: Synthesis Note on Urban Solid Waste Management Program of the Dakar Region, 15 pages.

[37] Onibokum AG 2000, urban waste management: solutions for Africa, IDRC - Karthala, 238 p.

[38] Djitte M., 2010, the management and development of computer equipment waste in Senegal: Diagnosis and proposal of a suitable legal and institutional framework. End of study memory, ISE / UCAD, 99 p.

[39] Boyle CA management in New Zealand Solid Waste Management 20 (2000) pp 517-526 CADAK-CAR, May 2007: Executive Summary on the Urban Waste Management Program Solid in the Dakar region, and IAGU CADAK-CAR, 15 p.

[40] Cisse O. 2007 waste money. The informal economy in Dakar, and CREPOS Karthala, $165 \mathrm{p}$. 